This is a preprint copy of a paper that was published in Philosophy Today 51 Supplement (2007): 33-41.

\title{
Heidegger's Distinction between Scientific and Philosophical Judgments
}

\author{
By Chad Engelland, \\ John Carroll University
}

In $\S 33$ of Being and Time, Martin Heidegger shows that judgment is a derivative phenomenon, and it owes its sense to the phenomenon of world. Later sections further root judgment in care and most originally in the self-articulation of timeliness. This could lead to the impression that phenomenology simply outflanks judgments. And yet every page of Being and Time teems with judgments. Each of the careful phenomenological analyses, from space to judgment to anxiety, deploys judgments to articulate the phenomena. Peculiarly, phenomenology uses judgments to situate judgments within a non-judicative context. Is Heidegger here guilty of a gross performative contradiction and methodological naïveté? Does Heidegger use the ladder to kick away the ladder as Carnap, Habermas, Edwards and others suppose ${ }^{1}$

Being and Time has its tensions and contradictions, but this is not one of them. We know from reading the methodological $§ 7$ that judgment or logos of any sort is in service to the selfshowing of phenomena. Timeliness, we later discover, introduces an essential bifurcation in the phenomena and thus implicates an essential difference between phenomenological and scientific judgments. Specifically, the horizonal-ecstatic unfolding of timeliness enables two different

\footnotetext{
${ }^{1}$ Jürgen Habermas criticizes what he calls Heidegger's “esoteric, special discourse, which absolves itself of the restrictions of discursive speech generally and is immunized by vagueness against any specific objections." Habermas thinks this disguises a "performative contradiction" in Heidegger's approach: "He makes use of metaphysical concepts for purposes of a critique of metaphysics, as a ladder he casts away once he has mounted the rungs." The Philosophical Discourse of Modernity: Twelve Lectures, trans. Frederick Lawrence (Cambridge: The MIT Press, 1987), 185. For similar claims, see Rudolph Carnap, "The Elimination of Metaphysics through the Logical Analysis of Language," trans. Arthur Pap, in Logical Positivism, ed. A. J. Ayer (Glencoe, Ill.: The Free Press, 1959), and, more recently, Paul Edwards, Heidegger's Confusions (Amherst, N.Y.: Prometheus Books, 2004).
} 
directions of inquiry. Scientific judgments are the result of turning from the timely openness to entities alone; phenomenological judgments are the result of returning to the timely openness in which such entities are accessible. Timeliness, then, makes the judgments differ in kind. Consequently, there is no contradiction for phenomenological judgments to be used to situate scientific judgments within a pre-judicative context.

To clarify the matter further, we could say that these two ways of judging are not univocal but analogical. That is, while what they signify is different, they are proportionately the same: scientific judgments are subordinate to the self-showing of entities as phenomenological judgments are subordinate to the self-showing of the timely horizon in which such entities can show themselves. Both are a way of "letting be seen" (Sehenlassen), but they differ because they manifest two essentially different possibilities of phenomena, the entitative and the timely. ${ }^{2}$ The latter is the condition for the possibility of the former. In this way we can see that Heidegger affirms the validity of science and its judgments as a legitimate possibility of discourse. He does think it entails a particular way of regarding things that is not the only way or even the most adequate way, but it is still a valid one. ${ }^{3}$ Contextualing scientific judgments within their ultimate horizon of sense enriches science and does not undermine it.

In registering this difference between the two judgments, we are hampered by the fact that the third division of Being and Time never appeared. In it, Heidegger tells us, he intended to develop the idea of phenomenology he had merely indicated in the methodological $§ 7 .{ }^{4}$

\footnotetext{
${ }^{2}$ Sein und Zeit, 18th ed. (Tübingen: Max Niemeyer Verlag, 2001), Being and Time, trans. John Macquarrie and Edward Robinson (New York: Harper \& Row, Publishers, 1962), 32-35/56-60, hereafter SZ. Throughout we will first list the pagination of the German edition followed by an English translation, should one be available (G/E).

${ }^{3}$ Saying of the hammer, "It is too heavy," is closer to life and so more meaningful than saying, "The hammer has such and such a mass." The latter is true but less meaningful than the former, since the former has regard for the world as the context of sense.

${ }^{4}$ Heidegger says that the transition from the preliminary conception of $\S 7$ to the idea of phenomenology in the third division can only be accomplished by clarifying the "connection" between being and truth in terms of timeliness: "Yet a fully adequate existential interpretation of science cannot be carried out until the sense of being
} 
Assuredly, this would have discussed the logos peculiar to phenomenology. Though Heidegger did not put everything in one place for us, we can still find clues in period lecture courses to present a cogent account of what he had in mind. ${ }^{5}$

\section{Time's Two Possibilities of Judgment}

The "unfolding and ripening" (Zeitigung) of "timeliness" (Zeitlichkeit) provides two basic possibilities for thematization and thus two basic possibilities for scientific discourse. ${ }^{6}$ On the one hand, entities can be unveiled in the manner of positive science and its apophantic discourse. On the other hand, being itself can be unveiled in the manner of phenomenological science and its timely discourse. Timeliness makes these two directions of unveiling both possible and necessary: "[T]imeliness is the root and the ground for both the possibility and, properly understood, the factical necessity of the objectification of the given entities and the given being."7 Positive science moves in the everyday direction toward entities, and

and the 'connection' between being and truth have been clarified in terms of the timeliness of existence. The following deliberations are preparatory to the understanding of this central problematic, within which, moreover, the idea of phenomenology, as distinguished from the preliminary conception of it which we indicated by way of introduction will be developed for the first time." SZ 357/408.

${ }^{5}$ Namely, we will have recourse to the following ways or works from the late 1920s: the 1925-26 Logik: Die Frage nach der Wahrheit, Gesamtausgabe 21, ed. Walter Biemel (Frankfurt am Main: Vittorio Klostermann, 1976), hereafter L; from 1927 Die Grundprobleme der Phänomenologie, Gesamtausgabe 24, ed. Friedrich-Wilhelm von Herrmann (Frankfurt am Main: Vittorio Klostermann, 1975), The Basic Problems of Phenomenology, rev. ed., trans. Albert Hofstadter (Bloomington: Indiana University Press, 1982), hereafter GP; the 1928 Metaphysische Anfangsgründe der Logik im Ausgang von Leibniz, Gesamtausgabe 26, ed. Klaus Held (Frankfurt am Main: Vittorio Klostermann, 1978), The Metaphysical Foundations of Logic, trans. Michael Heim (Bloomington: Indiana University Press, 1984), hereafter MAL; and from 1929-30 Die Grundbegriffe der Metaphysik. Welt—EndlichketEinsamkeit, Gesamtausgabe 29/30, ed. Friedrich-Wilhelm von Herrmann (Frankfurt am Main: Vittorio Klostermann, 1983), The Fundamental Concepts of Metaphysics, trans. William McNeill and Nicholas Walker (Bloomington: Indiana University Press, 1995), hereafter GM.

${ }^{6}$ In translating these and other key terms, I follow Daniel Dahlstrom's conventions in Heidegger's Concept of Truth (Cambridge: Cambridge University Press, 2001).

${ }^{7}$ GP 456/321. What "objectification" means here is important: "Science is a cognizing for the sake of unveiledness as such. . . . What is to be unveiled is the sole court of appeal of its determinability, of the concepts that are suitable for interpreting it." GP 455/320. What is so "objectified" must be given beforehand and so is in no way the product of construction. Nonetheless, it does involve projection: for positive science the "projection of the ontological constitution of a region of entities," and for ontology the "projection of being upon the horizon of its understandability," namely time. GP 457-459/321-322. 
phenomenological research moves in the counter tendency toward the projection of being in terms of timeliness.

The basic act of phenomenological science is the "objectification"

(Vergegenständlichung) of being. Now, Heidegger does not mean that being is made into an object opposite a subject but only that it is understood in light of the self-unfolding of timeliness. ${ }^{8}$ Being and its timely sense are for the most part covered up, and phenomenological science has the task of bringing these phenomena to explicit givenness. Heidegger does not blush when he calls this task "objectification," because he means it in an essentially different sense than positive science. While positive science unveils entities as such by projecting the ontological constitution of a region of entities, phenomenology unveils being as such by projecting it upon the timely horizon of its understandability. But it is this horizon of understandability that the philosophical tradition has not methodologically secured: "The history of philosophy bears witness that all ontological interpretations, with regard to the horizon essentially necessary for them and to the assurance of that horizon, are more like a groping about than a definite methodical inquiry." 9 Why is it that this "basic act" is so overlooked? Why is it that it "is delivered up to uncertainty and stands continually in danger of being reversed"? ${ }^{10}$ Because it "must necessarily move in a projective direction that runs counter to everyday comportment towards entities." The two directions of unveiling, then, are rooted in the two

\footnotetext{
${ }^{8}$ He does, however, hold back the third division in order to avoid the appearance of making being into an object opposite a subject. See his comments in Beiträge zur Philosophie (Vom Ereignis), Gesamtausgabe 65, ed. Friedrich-Wilhelm von Herrmann (Frankfurt am Main: Vittorio Klostermann, 1989), Contributions to Philosophy (From Enowning), trans. Parvis Emad and Kenneth Maly (Bloomington: Indiana University Press, 1999), 450/317, and "Der europäische Nihilismus," in Nietzsche, vol. II (Pfullingen: Verlag Günther Neske, 1961), "European Nihilism," in Nietzsche, vol. IV, ed. David Farrell Krell, trans. Frank A. Capuzzi (New York: Harper \& Row, 1982), 194-195/141-142.

${ }^{9}$ GP 459/322.

${ }^{10}$ GP $459 / 323$.
} 
directions of Dasein: either (1) falling inauthenticity and the on-hand in general or (2) resolute authenticity and the phenomenon of timeliness.

The difference between these two is secured through the method of "formal indication" (formale Anzeige). ${ }^{11}$ When philosophy is expressed it is subject to two persistent misinterpretations by the common understanding, which interprets what is meant as "on-hand" (vorhanden) and "isolated." That is to say, the common understanding falls into the "natural error" of understanding "any philosophical explication it encounters in its own terms, as an assertion about certain characteristic features of entities as on-hand."12 Because it interprets philosophical phenomena as on-hand, it also takes "relations" to other phenomena to be properties of an "on-hand" entity. Due to its "natural idleness,"13 common understanding thus passes over the authentic philosophical task of transformation in which Dasein is not regarded as an on-hand entity but as an opportunity for existential intensification through conceptualization. ${ }^{14}$ The authentic philosophic task of transforming Dasein likewise indicates that "the one and only originary interconnection of concepts is already established through Dasein itself." 15 Such an originary interconnection is unfolded in the self-articulation of timeliness. Formal indication, which leads philosophy to transformation, shows itself as the proper antidote to the natural proclivity of the common understanding toward isolated

${ }^{11}$ On formal indication, see Theodore Kisiel, The Genesis of Heidegger's Being and Time (Berkeley: The University of California Press, 1993), especially 456; Steven Crowell, Husserl, Heidegger, and the Space of Meaning (Evanston, Ill.: Northwestern University Press, 2001), 137-144; and Dahlstrom, "Heidegger's Method: Philosophical Concepts as Formal Indications," Review of Metaphysics 47 (1994): 775-95. Kisiel calls it "the very fulcrum of Being and Time," though in the published divisions Heidegger is largely silent about its role. Genesis, $172 \mathrm{n} 4$.

${ }^{12}$ GM 430-431/297.

13 GM 423/292.

14 "[W] hat philosophy deals with only discloses itself at all within and from out of a transformation of human Dasein." GM 423/292.

${ }^{15}$ GM 432/298. 
objectification. It serves as an invitation to turn authentically to the original phenomenon of timeliness and articulate its essential structures.

Formal indication, then, shows the way to the differentiation of these two directions of judgment, either toward on-hand entities or the timely unfolding of being. To move from the one to the other is a difficult task. Heidegger notes phenomenology lacks not only the right words "but, above all, the right 'grammar.",16 Instead of a grammar fitted to on-hand things, what is needed is formal language fitted to the timely openness. As Theodore Kisiel puts it, “Heidegger's sense of formality is derived, not from a formal mathesis of objects linked to the substantifying tradition of philosophy, but from a non-objective gramma(on)tology of time's tenses." ${ }^{17}$ Preliminarily, then, we can say that scientific and everyday judgments concern decontextualized entities, but that phenomenological judgments concern the timely constitution of the openness in which entities can be disclosed.

\section{Scientific Judgments Miss the Timely Horizon}

Scientific or positive judgments are fitted to on-hand entities. Heidegger calls the circumspective interpretation that issues in such judgment, "deliberation," and says it is founded on a structure of retention and awaiting. The equipmental whole (the "towards-this") is retained and the possibility (the "towards-which") is awaited. Within this timely structure, makingpresent can bring something closer in interpretation. Circumspective making-present "is grounded in a retention of that context of equipment with which Dasein concerns itself in

\footnotetext{
${ }^{16}$ SZ 39/63.
}

17 "The Genetic Difference in Reading Being and Time," American Catholic Philosophical Quarterly 69 (1995): 182. Kisiel very densely but ably sketches the differences between the language of this temporal science and the language of traditional ontology: "The very fact that Being and Time stresses, and even overstresses, prepositional schematisms must be understood in the larger context of a comprehensive grammatology bent upon a thorough re-view and revision of the formal grammars of our classical languages, where the focus shifts from 
awaiting a possibility. That which has already been laid open in awaiting and retaining is brought closer by one's deliberative making-present or envisaging."18 To bring closer is "to let that in which something has an involvement, be seen circumspectively as this very thing." 19 For the interpretation to bring something close, it must fit itself to the being of that which is interpreted.

The way the present is rooted in the future and in having been, is the existential-timely condition for the possibility that what has been projected in circumspective understanding can be brought closer in a making-present, and in such a way that the present can thus fit [anmessen] itself to what is encountered within the horizon of awaiting and retaining; this means that it must interpret itself in the schema of the as-structure. . . . Like understanding and interpretation in general, the "as" is grounded in the ecstaticohorizonal unity of timeliness. ${ }^{20}$

Scientific judgments arise by a modification of this timely hermeneutical "as" of the understanding. Instead of taking something as handy for some task within a field of reference, in science we focus on the entity as on-hand for inspection. We register its properties and issue judgments about what it is. ${ }^{21}$ The sense of the judgment is borrowed, because it is derived from the timely hermeneutic synthesis in which the entity is originally uncovered. The leveling of syntheses from hermeneutical "as" to apophantic "is" occurs in the withdrawal of the timely horizon of awaiting and retaining toward which something could have sense.

The narrowing of interest that issues in a scientific judgment occurs in three overlapping stages. (a) Proximately, we are immersed in the context of meaning deliberating with an entity

substantives to middle-voiced infinitives, reflexives, double genitives, transitive-intransitive relations, and the exclamatory impersonals of happenings."

${ }^{18}$ SZ 359/411.

${ }^{19}$ SZ 360/411. Cf. SZ 33/56.

${ }^{20}$ SZ 360/411.

${ }^{21}$ Thomas Prufer characterizes this transition as the suppression of "the unthematic synthesis of something together with whatever we take it as (being) useful for" and its replacement "by the thematic predicative synthesis: saying something as (being) a characteristic of something." He relates these two syntheses as follows: "The predicative truth of something characterized as being so is secondary to and rooted in the prepredicative good of something taken as being useful for." Recapitulations: Essays in Philosophy (Washington, D.C.: The Catholic University of America Press, 1993), 80, 81. 
in the mode of handiness. Our understanding refers it to the totality of our involvements. We simply employ the hammer for the sake of some task. The hammer is embedded within the matrix of relations constitutive of our concernful being-in-the-world. (b) Subsequently, we may say something about the hammer which involves a change in the entity's mode from handiness to on-handness. ${ }^{22}$ We might say, for instance, "This hammer is heavy." The reference of the entity to the totality of our involvements withdraws and our preview only sees something in the mode of on-handness in the midst of what is handy. The emergence of on-hand entities obscures the mode of handiness, and it enables discussion of an entity's features, of its having a definite character. $^{23}$ (c) But we can further draw on its being on-hand as such and then speak of its properties, saying, for instance, that it has certain chemical properties. Here we are discussing the entity simply as a "what.",24

This emergence of the on-hand in the flattening of the "as" trades on an abrupt timely shift in the understanding of being. ${ }^{25}$ We pass over the hammer's handy kind of being, and look at (ansehen) the handy entity simply as on-hand. Consequently the hammer loses its sense:

We have now sighted something that is suitable for the hammer, not as a tool, but as a corporeal thing subject to the law of gravity. The circumspective discourse of "too heavy" or "too light" no longer has any "sense" that is to say, the entity in itself, as we now encounter it, gives us nothing with relation to which [worauf] it could be "found" too heavy or too light. ${ }^{26}$

Sense comes from the unfolding of the timely context of understanding and interpretation. Thus, in this shift in understanding, the timely horizon of retaining the equipmental context and awaiting the possibility has been passed over. Judgments arise when the horizon of sense

${ }^{22} \mathrm{SZ} 158 / 200$.

${ }^{23}$ In this regard, Hubert Dreyfus says that on-hand entities are decontextualized, revealing "context-free features and properties." Being-in-the-World: A Commentary on Heidegger's Being and Time, Division I (Cambridge, Mass.: The MIT Press, 1991), 84.

${ }^{24}$ SZ 158/200.

25 "The understanding of being by which our concernful dealings with entities within-the-world have been guided has changed over." SZ 361/412. 
recedes leaving the bare entity, but the sense of the judgment derives from the very horizon that is thereby missed.

Though we have isolated three moments, there is a spectrum of gradations from a concerned understanding of a handy entity to its being taken as the object of a theoretical assertion. $^{27}$ Accounts of the handy, discussions of events, reports, and the like cannot be reduced to bare theoretical assertions without falsification, since they are much closer than theoretical assertions to the origin in a concerned understanding.

\section{Phenomenological Judgments Articulate the Timely Horizon}

Phenomenological judgments do not allow the timely horizon to recede from view.

Instead, they articulate the constitution of sense or the openness in which entities are accessible. The unfolding of timeliness always already opens the world in which we can encounter entities as handy or on-hand. Timeliness accomplishes such an opening, because it is self-articulating; in its unfolding or ripening it articulates itself ecstatically and horizonally. Time, as both horizonal and ecstatic, "unfolds itself, oscillating as a worlding [Welten]." 28 Through this unfolding the world itself "is." 29

Authentic timeliness is prior to divisions between subjective and objective or immanent and transcendent. "Timeliness is not ... an entity which first emerges from itself; its essence is unfolding in the unity of the ecstasies." 30 Heidegger thus identifies timeliness as "the primordial

${ }^{26} \mathrm{SZ} 361 / 412$.

${ }^{27}$ SZ 158/201.

${ }^{28}$ MAL 270/209.

${ }^{29}$ Cf. SZ 365/417: "In so far as Dasein unfolds itself, a world is too. In unfolding itself with regard to its being as timeliness, Dasein is essentially 'in a world,' by reason of the ecstatico-horizonal constitution of that timeliness. The world is neither on-hand nor handy, but unfolds itself in timeliness. It 'is,' with the 'outside-ofitself' of the ecstasies, 'here."”

${ }^{30}$ SZ 329/377. 
'outside-itself' in and for itself." "31 Due to this "ec-static," outside-itself, character, Heidegger terms the threefold timely phenomena "ecstasies."

In unfolding, timeliness unfurls the basic directions for our existence. Each of the three timely ecstasies carries us in a different horizonal schema, its "whereto" (Wohin). ${ }^{32}$ The horizonal schema of coming-towards is the for-the-sake-of-which; of having-been is in the face of which and to which; of making-present is the in-order-to. The horizon of timeliness is the unity of these three schemata. Such a unity makes sense and world possible. ${ }^{33}$

The horizon of timeliness as a whole determines that toward-which factically existing entities are essentially disclosed... . The horizonal unity of the schemata of these ecstasies makes possible the primordial way in which the relationships of the "in-orderto" are connected with the "for-the-sake-of." This implies that on the basis of the horizonal constitution of the ecstatical unity of timeliness, there belongs to that entity which is in each case its own "here," [i.e., Da-sein] something like a world that has been disclosed. $^{34}$

Sense, or what Heidegger calls "being,"35 is the "toward-which" of a projection that enables understandability and thus meaning. Meaning, in turn, is the totality of references constitutive of world. Timeliness, then, horizonally unites being (sense) and world (meaning) such that entities within the world can be meaningfully encountered or disclosed. ${ }^{36}$

Thus the relations of meaningfulness which determine the structure of the world are not a network of forms which a worldless subject has laid over some kind of material. What is rather the case is that factical Dasein, understanding itself and its world ecstatically in the unity of the here, comes back from these horizons to the entities encountered within them. Coming back to these entities understandingly is the existential

${ }^{31} \mathrm{SZ} 329 / 377$.

${ }^{32}$ SZ 365/416.

33 "The existential-timely condition for the possibility of the world lies in the fact that timeliness, as an ecstatical unity, has something like a horizon." SZ 365/416.

${ }^{34}$ SZ 365/416-417.

${ }^{35}$ GP 429/302.

${ }^{36}$ Heidegger's language of horizon is frequently criticized, but I think it is a helpful formal indication of the connection of ecstatic timeliness and world; it suggests a non-static limit that determines and enables a finitude not subject to Hegelian dialectic. For criticisms, see Kisiel, Genesis, 449-451, and John van Buren, The Young Heidegger: Rumor of the Hidden King (Bloomington: Indiana University Press, 1994), 363-367. Dahlstrom provides a helpful treatment of horizon, Heidegger's Concept of Truth, 333-337. 
sense of letting them be encountered by making them present; that is why we call them entities "within-the-world.",37

Dasein, constituted by timeliness, finds itself within a horizon and faced with disclosed entities.

It can either turn to the entities disclosed within the horizon in scientific discourse or it can turn

to the horizon itself in phenomenological discourse.

Timeliness enables sense and thereby opens world for Dasein by serving as the ultimate context of understanding's projection. Time is self-interpreting and articulates itself in accordance with horizonal ecstasies, and therefore it serves as the end and source of projection. ${ }^{38}$

Because the ecstatic-horizonal unity of timeliness is intrinsically self-projection pure and simple, because as ecstatic it makes possible all projecting upon . . . and represents, together with the horizon belonging to the ecstasis, the condition of possibility of a toward-which, an out-toward-which in general, it can no longer be asked upon what the schemata can on their part be projected, and so on in infinitum. ${ }^{39}$

Phenomenology as it were listens in on the self-articulating of timeliness and brings it to disclosure and articulation. Consequently, the propositions of this science are themselves temporal: "All the propositions of ontology are temporal propositions. Their truths unveil structures and possibilities of being in the light of temporality. All ontological propositions have the character of temporal truth, veritas temporalis."40

Phenomenological propositions articulate the complete unity of timeliness. Heidegger calls them a priori propositions, because they lay bare what is always already unfolded in authentic timeliness. To make this sense of completion clear, he even calls the "tense" at work

${ }^{37}$ SZ 366/417.

${ }^{38}$ The datability of discourse attests to this: "The fact that the structure of datability belongs essentially to what has been interpreted with the 'now,' and the 'then,' and the 'on that former occasion,' becomes the most elemental proof that what has thus been interpreted has originated in the timeliness which interprets itself." SZ $408 / 460$.

${ }^{39}$ GP 437/307-308. He continues: "The series, mentioned earlier, of projections as it were inserted one before the other - understanding of entities, projection upon being, understanding of being, projection upon timehas its end at the horizon of ecstatic unity of timeliness. [ . . . ] But this end is nothing but the beginning and starting point for the possibility of all projecting."

${ }^{40} \mathrm{GP} 460 / 323$. 


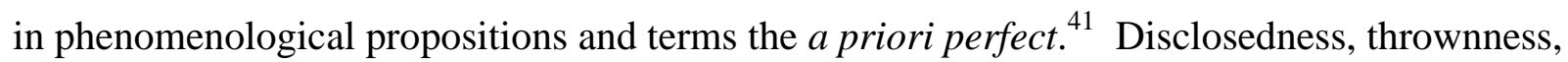
disposedness, and discoveredness are accordingly in the perfect tense, but so are all the formallyindicated terms of the structure that lets entities be. This leads Thomas Sheehan to say that Dasein, which is always already opened, should be translated as openedness. ${ }^{42}$ Timeliness unfolds ecstatically and horizonally and thereby always already opens the site in which we encounter things. Phenomenological assertions articulate the timely constitution of this openness and thereby exhibit what makes entities accessible. ${ }^{43}$ Heidegger even takes to Latinate terms when speaking of timeliness as enabling this a priori openness. In the following passage, for instance, he experiments with "praesens" to name the timely horizon of awaiting and retaining:

The handiness of the handy, the being of these entities, is understood as praesens, a praesens which, as non-conceptually understandable, is already unveiled in the selfprojection of timeliness, by means of whose unfolding anything like existent dealings with the handy and on-hand become possible. ${ }^{44}$

By means of praesens, entities can be available or unavailable, present or absent. ${ }^{45}$ The timely logos of phenomenology, then, articulates the openness in which everyday judgments and the judgments of science are possible. Rather than a grammar of on-hand entities, Heidegger develops a grammar of timeliness' dynamic unfolding that lets entities be. Nor does this theme simply drop from view in his later thought. As Heidegger tells us, timeliness or transcendence approached "from the truth of being" is called "appropriation" (Ereignis). ${ }^{46}$

${ }^{41} \mathrm{SZ} 85 / 117$. In a later marginal note to this passage, Heidegger says he finds precursors for this tense in both Aristotle's ontology and Kant's transcendental philosophy. On the importance of this tense, see Kisiel, Genesis, 392-3 and 404.

${ }^{42}$ See "Geschichtlichkeit/Ereignis/Kehre," Existentia: Meletai Sophias 11 (2001): 242-246.

43 "Time is earlier than any possible earlier of whatever sort, because it is the basic condition for an earlier as such. And because time as the source of all enablings (possibilities) is the earliest, all possibilities as such in their possibility-making function have the character of the earlier. That is to say, they are a priori." GP 463/325.

${ }^{44}$ GP 438-439/309. Heidegger italicizes the whole passage.

${ }^{45}$ GP 429-444/302-312.

${ }^{46}$ Marginalia to SZ 440. See Sheehan, "Kehre and Ereignis: A Prolegomenon to Introduction to Metaphysics," in A Companion to Heidegger's 'Introduction to Metaphysics', ed. Richard Polt and Gregory Fried (New Haven: Yale University Press, 2001), 15. 


\section{Conclusion}

Timeliness is self-interpreting and articulates itself in accord with the timely ecstasies and the ontological difference: "On the basis of timeliness there belongs to Dasein's existence the immediate unity of the understanding of being and comportment toward entities." ${ }^{\text {"4 }}$ It thus provides essentially two directions for inquiry: (1) we can follow the falling tendency of the everyday and thematize the on-hand in the manner of science; or (2) we can resolutely hold ourselves in the counter-tendency toward the horizon itself and thematize being in the manner of phenomenological philosophy. ${ }^{48}$ Understanding can be developed in interpretation either (1) inauthentically or (2) authentically; it can consequently issue in either (1) scientific assertions about entities or (2) phenomenological ones about timeliness and being.

Because no readily discernible feature of an assertion identifies it as scientific or phenomenological, the appearance of a performative contradiction and methodological naïveté is unavoidable. If the timely difference is missed, Heidegger's phenomenological propositions appear to be vague assertions about entities, and he is understandably criticized for a "wool gathering" that runs counter to the rigor of scientific logos. If, on the contrary, the difference is cultivated in self-transformation, the timely sense and its grammar shine with a clarity and rigor of their own. ${ }^{49}$ Then we can see that Heidegger's phenomenological judgments contextualize but

${ }^{47}$ GP 454/319.

${ }^{48}$ Cf. Kisiel's characterization: "The vectorial thrust of time's transcendence and counter-thrust of its decadence and degeneration are . . the ultimate basis for the existential polar opposites that structure the self in Being and Time: my-self and they-self, authentic and inauthentic, originative timeliness and everydayness." "The New Translation of Sein und Zeit: A Grammatological Lexicographer's Commentary," in Heidegger's Way of Thought: Critical and Interpretative Signposts by Theodore Kisiel, ed. Alfred Denker and Marion Heinz (New York: Continuum, 2002), 76.

${ }^{49}$ Ambiguously, a philosophical proposition provides two directives: it both indicates the timely transformation of Dasein and signifies the on-hand. To understand it rightly entails following the indicated conceptualization oneself; to misunderstand it entails reducing everything it talks about to an object. The following passage from 1926 notes the difference that we must master: "All assertions about the being of Dasein, all propositions about time, all propositions within the problematic of temporality have, as pronounced propositions, the character of indication [Anzeige]: they indicate [indizieren] only Dasein, while as pronounced propositions they 
do not annul scientific judgments. No ladder is kicked away. Rather, Heidegger recognizes that there is more to logos than logic, because there is necessarily more to phenomena than what is merely on-hand.

Later Heidegger becomes disillusioned with the analogy between scientific judgments and phenomenological ones. It gives rise to the unwanted appearance that being is made an object opposite a subject. ${ }^{50}$ He accordingly desires to move beyond phenomenology as a research program by developing a manner of doing phenomenology on the basis of thrownness rather than projection. He turns to a more poetic discourse attuned by fundamental moods. ${ }^{51}$ And yet, the analogy with poetry comes with its own danger, and his later thought can appear merely mystifying. Even after 1959, Heidegger complained to Pöggeler that "while he had gathered all the basic thoughts, he still lacked the language — one cannot just poetize." ${ }^{, 52}$ It is for this reason that Gadamer is perhaps justified, against every hint Heidegger provides, to emphasize that formal indication — and we might add the timeliness of phenomenological judgments — is a fruitful manner of doing philosophy alongside Heidegger, early and late: “All of us should ever be relearning that when Heidegger spoke in his early works of 'formal indication,' he already formulated something that holds for the whole of his thought."53

nevertheless above all signify the on-hand; they indicate Dasein and the structure of Dasein and of time, they indicate the possible understanding and the possible conceivability of the structure of Dasein, which is accessible in such understanding." L 410.

${ }^{50}$ See note 8 above.

${ }^{51}$ Cf. SZ 162/205: "In 'poetical' discourse, the communication of the existential possibilities of one's disposedness can become an aim in itself, and this amounts to a disclosing of existence."

${ }^{52}$ Otto Pöggeler, Martin Heidegger's Path of Thinking, trans. Daniel Magurshak and Sigmund Barber (Atlantic Highlands, N.J.: Humanities Press International, Inc., 1987), 287.

${ }^{53}$ Hans-Georg Gadamer, "Martin Heidegger's One Path," trans. P. Christopher Smith, in Reading Heidegger from the Start: Essays in His Earliest Thought, ed. Theodore Kisiel and John van Buren (Albany, New York: State University of New York Press, 1994), 33. What Gadamer has in mind can be gathered from the following words: "The 'formal indication' points us in the direction in which we are to look. We must learn to say what shows up there and learn to say it in our own words." 


\section{Works Cited}

Carnap, Rudolph. "The Elimination of Metaphysics through the Logical Analysis of Language." Translated by Arthur Pap. In Logical Positivism, ed. A. J. Ayer. Glencoe, Ill.: The Free Press, 1959.

Crowell, Steven. Husserl, Heidegger, and the Space of Meaning. Evanston, Ill.: Northwestern University Press, 2001.

Dahlstron, Daniel. "Heidegger's Method: Philosophical Concepts as Formal Indications." Review of Metaphysics 47 (1994): 775-95. . Heidegger's Concept of Truth. Cambridge: Cambridge University Press, 2001.

Dreyfus, Hubert. Being-in-the-World: A Commentary on Heidegger's Being and Time, Division I Cambridge, Mass.: The MIT Press, 1991.

Edwards, Paul. Heidegger's Confusions. Amherst, N.Y.: Prometheus Books, 2004.

Gadamer, Hans-Georg. "Martin Heidegger's One Path.” Translated by P. Christopher Smith. In Reading Heidegger from the Start: Essays in His Earliest Thought, ed. Theodore Kisiel and John van Buren, 19-34. Albany, N.Y.: State University of New York Press, 1994.

Habermas, Jürgen. The Philosophical Discourse of Modernity: Twelve Lectures. Translated by Frederick Lawrence. Cambridge, Mass.: The MIT Press, 1987.

Heidegger, Martin. Beiträge zur Philosophie (Vom Ereignis). Gesamtausgabe 65. Edited by Friedrich-Wilhelm von Herrmann. Frankfurt am Main: Vittorio Klostermann, 1989. Contributions to Philosophy (From Enowning). Translated by Parvis Emad and Kenneth Maly. Bloomington: Indiana University Press, 1999.

. "Der europäische Nihilismus." In Nietzsche, vol. II. Pfullingen: Verlag Günther Neske, 1961. "European Nihilism." In Nietzsche, vol. IV. Edited by David Farrell Krell. Translated by Frank A. Capuzzi. New York: Harper \& Row, 1982.

. Die Grundbegriffe der Metaphysik. Welt-Endlichket-Einsamkeit. Gesamtausgabe 29/30. Edited by Friedrich-Wilhelm von Herrmann. Frankfurt am Main: Vittorio Klostermann, 1983. The Fundamental Concepts of Metaphysics. Translated by William McNeill and Nicholas Walker. Bloomington: Indiana University Press, 1995.

. Die Grundprobleme der Phänomenologie. Gesamtausgabe 24. Edited by FriedrichWilhelm von Herrmann. Frankfurt am Main: Vittorio Klostermann, 1975. The Basic Problems of Phenomenology, rev. ed. Translated by Albert Hofstadter. Bloomington: Indiana University Press, 1982. 
Logik: Die Frage nach der Wahrheit. Gesamtausgabe 21. Edited by Walter Biemel. Frankfurt am Main: Vittorio Klostermann, 1976.

. Metaphysische Anfangsgründe der Logik im Ausgang von Leibniz. Gesamtausgabe 26. Edited by Klaus Held. Frankfurt am Main: Vittorio Klostermann, 1978. The Metaphysical Foundations of Logic. Translated by Michael Heim. Bloomington: Indiana University Press, 1984.

. Sein und Zeit, 18th ed. Tübingen: Max Niemeyer Verlag, 2001. Being and Time. Translated by John Macquarrie and Edward Robinson. New York: Harper \& Row, Publishers, 1962.

Kisiel, Theodore. The Genesis of Heidegger's Being and Time. Berkeley: The University of California Press, 1993.

. "The Genetic Difference in Reading Being and Time." American Catholic Philosophical Quarterly 69 (1995): 171-87.

. "The New Translation of Sein und Zeit: A Grammatological Lexicographer's Commentary." In Heidegger's Way of Thought: Critical and Interpretative Signposts by Theodore Kisiel, ed. Alfred Denker and Marion Heinz. New York: Continuum, 2002.

Pöggeler, Otto. Martin Heidegger's Path of Thinking. Translated by Daniel Magurshak and Sigmund Barber. Atlantic Highlands, N.J.: Humanities Press International, Inc., 1987.

Prufer, Thomas. Recapitulations: Essays in Philosophy. Washington, D.C.: The Catholic University of America Press, 1993.

Sheehan, Thomas. "Geschichtlichkeit/Ereignis/Kehre.” Existentia: Meletai Sophias 11 (2001): 241-51.

. "Kehre and Ereignis: A Prolegomenon to Introduction to Metaphysics." In A Companion to Heidegger's 'Introduction to Metaphysics', ed. Richard Polt and Gregory Fried, 3-16. New Haven: Yale University Press, 2001.

van Buren, John. The Young Heidegger: Rumor of the Hidden King. Bloomington: Indiana University Press, 1994. 